\title{
Evaluation of Some Sorghum Genotypes for the Susceptibility to Sorghum Head Bug Eurystylus Sp (Hemiptera; Miridae) in the Blue Nile State, Sudan
}

\author{
*Eisa Y. A., Ali E. A., Abubaker A. A. \\ Damazin Research Station, Agricultural Research Corporation, Sudan
}

*Corresponding Author: Eisa Y. A., Damazin Research Station, Agricultural Research Corporation Sudan.

Received Date: 05-04-2017

Accepted Date: 12-04-2017

Published Date: 12-05-2017

\begin{abstract}
The change from traditional to new high-yielding sorghum cultivars with shorter crop maturity cycles and more compact head types, increase panicle insect problems over all the world. The study was designed to evaluate different sorghum genotype for the sorghum head bugs susceptibility. The experiment was conducted at the Blue Nile State, Damazin Research Station Farm, during the 2013/2014, 2014/2015 and 2015/2016 cropping seasons, respectively. The Design used was randomized complete block design (RCBD) and consisted of four replications. Plot size was $7 x 5 \mathrm{~m}^{2}$, spacing $0.80 \mathrm{~m}$ between rows and $10 \mathrm{~cm}$ within rows. Two counts were done at milk and soft dough stages to determine head bug density / panicle. Generally compact heads genotypes, Wad Ahmed, Um Benain, showed the highest number of bugs and Mehaireba and Botana (loose and semi-compact heads) was recorded the lowest number of head bugs.
\end{abstract}

Keywords: Sorghum, Compact, Head bugs, Genotypes, Panicle.

\section{INTRODUCTION}

Sorghum is the fourth most important world cereals crop following wheat, rice, and maize. It is a staple food in the drier part of Africa, china and India. Sorghum is a cereal grain crop mostly grown in Africa, Asia and Central America. Nigeria and Sudan contribute nearly half of the sorghum production in Africa (Thabit, 2015).

Panicle feeding insects cause yield loss and reduction in grain quality. Forty-two panicle feeding insect pests have been recorded in Africa (Ratnadass and Ajayi, 1995). Miridae head bugs are important pests of sorghum in Asia and Africa, and it has gave attention in recent years as an economic pest of sorghum, that causes severe yield losses wherever they are found (Showemimo, 2005). The damage of head bugs starts as soon as the panicle emerges from the boot leaf, the nymphs and adults suck the sap from the developing grain and occasionally on tender parts of the sorghum panicle (Sharma et al. 1992a).. Head bug damage create quantitative and qualitative losses and thereby leading to a loss of over $80 \%$ of the crop, however, if damage is done at early stages of grain development, it could result in total crop failure (Ajayi and Tabo,1995).

\section{MATERIALS ANd MethodS}

The experiment was conducted in the Blue Nile State, Damazin Research Station Farm during seasons 2013/14, 2014/15 and 2015/16, 13 sorghum genotypes for the first season and 16 sorghum genotypes in the second and third seasons (local and improved) Wad Ahmed, Tabat, Butana, Bashaeir, Arfa Gadamak, Um Benean, Meheariba, Karamaka, Mogod, Wad Akar, kolum, Torkash, Wad Yapis, ICSV93075, BS.D6 and Edo 16.dw was used with the different panicle type compact, semi-compact and loose head were sown on 14, 19 and 27 July, during the first, second and third season respectively. The Design used was randomized complete block design (RCBD) and consisted of four replications. Plot size was 7x $5 \mathrm{~m}^{2}$, spacing $0.80 \mathrm{~m}$ between rows and $10 \mathrm{~cm}$ within rows. Two counts were done at milk and soft dough stages. Five panicles were randomly selected from each plot covered using a polyethylene bag and shaken vigorously to dislodge all head bugs on it. Insects collected were taken to the laboratory and kept in a refrigerator for hours to make them immobile and head bugs number per head were counted. For the grain yield, two middle rows were harvested from each plot and their yield was converted to ton/fed. 
Evaluation of Some Sorghum Genotypes for the Susceptibility to Sorghum Head Bug Eurystylus Sp (Hemiptera; Miridae) in the Blue Nile State, Sudan

Data collected were transformed to appropriate transformation whenever it was necessary and analyzed using Analysis of Variance (ANOVA) and Duncan Multiple Range Test (DMRT) to separate means.

\section{The Results}

\section{Season 2013/2014}

From the results obtained (Table 1) there were significant differences between the tested genotypes in number of head bugs/panicle in the first and second counts. The highest number of bugs/panicle was recorded on (Mogod, ICSV93075, Karamaka, Wad Ahmed, Um Benain, Arfa Gadamak, Wad Akar,...) and the Lowest was recorded on ( Meheariba, Basheir, Botana and Tabat) in the two counts. There were significant differences in grain yield the highest yield recorded by Wad Akar followed by Botana (Table 1).

Table1. Mean number of sorghum head bugs / panicle, and yield for different sorghum genotypes, season 2013/ 2014.

\begin{tabular}{|l|l|l|l|l|}
\hline \multirow{2}{*}{ Genotype } & \multirow{2}{*}{ Compactness } & \multicolumn{2}{|c|}{ No. of bugs/panicle } & \multirow{2}{*}{$\begin{array}{c}\text { Yield } \\
\text { ton/fed }\end{array}$} \\
\cline { 3 - 5 } & & $1^{\text {st }}$ count & \multicolumn{1}{|c|}{$2^{\text {nd }}$ count } & $0.70 \mathrm{ab}$ \\
\hline Wad Ahmed & Compact & $(4.8) 2.3 \mathrm{abc}$ & $(7.6) 2.8 \mathrm{a}$ & $0.86 \mathrm{ab}$ \\
\hline Tabat & Compact & $(1.6) 1.4 \mathrm{~d}$ & $(2.0) 1.6 \mathrm{def}$ & $0.91 \mathrm{ab}$ \\
\hline Botana & Loose & $(2.2) 1.7 \mathrm{~cd}$ & $(2.0) 1.6 \mathrm{def}$ & $0.60 \mathrm{~b}$ \\
\hline Basaheir & Loose & $(2.9) 1.8 \mathrm{abcd}$ & $(3.4) 1.8 \mathrm{cdef}$ & $0.85 \mathrm{ab}$ \\
\hline Arfa Gadamak & Compact & $(2.5) 1.7 \mathrm{bcd}$ & $(2.9) 1.9 \mathrm{cdef}$ & $1.0 \mathrm{ab}$ \\
\hline Um Benain & compact & $(5.4) 2.2 \mathrm{abcd}$ & $(4.2) 2.1 \mathrm{bcde}$ & $0.73 \mathrm{ab}$ \\
\hline Meheariba & Loose & $(1.6) 1.4 \mathrm{~d}$ & $(1.9) 1.5 \mathrm{ef}$ & $0.74 \mathrm{ab}$ \\
\hline Karamaka & Loose & $(6.0) 2.5 \mathrm{ab}$ & $(1.4) 1.4 \mathrm{f}$ & $0.83 \mathrm{ab}$ \\
\hline Mogod & Compact & $(6.5) 2.6 \mathrm{a}$ & $(4.7) 2.3 \mathrm{abc}$ & $1.28 \mathrm{a}$ \\
\hline Wad Akar & Compact & $(4.1) 2.1 \mathrm{abcd}$ & $(4.2) 2.2 \mathrm{bcd}$ & $0.87 \mathrm{ab}$ \\
\hline ICSV93075 & Semi-compact & $(6.2) 2.6 \mathrm{a}$ & $(3.4) 2.0 \mathrm{bcdef}$ & $0.80 \mathrm{ab}$ \\
\hline BS.D6 & Semi-compact & $(3.6) 2.0 \mathrm{abcd}$ & $(5.8) 2.5 \mathrm{ab}$ & $0.79 \mathrm{ab}$ \\
\hline Edo 16 dw & Semi-compact & $(3.7) 2.0 \mathrm{abcd}$ & $(3.2) 1.9 \mathrm{bcdef}$ & 0.18 \\
\hline SE \pm & & 0.27 & 0.19 & 38.7 \\
\hline C.V\% & & 23.3 & 17.7 & \\
\hline
\end{tabular}

Means followed by the same letter $(s)$ are not significantly different

Some data transformed to $\sqrt{ } x+0.5$

Means in parenthesis are actual data

\section{Season 2014/2015}

The different sorghum genotypes showed a high significant difference in the first and second counts for head bug preference. Wad Acar, Wad Yapis, Wad Ahed, Arfa Gadamak, Um Benain,
Torkash and Kolum had the highest number of bugs/ panicle in both counts.

Tabat, Bs. D.6, Boutana, Edo. $16 \mathrm{dw}$ recoded the lowest number of bugs/panicle. The high yield was recorded by Wad Yapis, W. Ahmed, Tabat and ICSV 93075 (Table 2).

Table2. Mean number of sorghum head bugs / panicle, and yield for different sorghum genotypes, season $2014 / 2015$

\begin{tabular}{|c|c|c|c|c|}
\hline \multirow[t]{2}{*}{ Genotype } & \multirow[t]{2}{*}{ Compactness } & \multicolumn{2}{|c|}{ No. of bugs/panicle } & \multirow[t]{2}{*}{ Yield ton/fed } \\
\hline & & $1^{\text {st }}$ count & $2^{\text {nd }}$ count & \\
\hline Wad ahmed & Compact & $12.0 \mathrm{ab}$ & (2.8) $1.8 \mathrm{abc}$ & (0.54) $1.02 \mathrm{ab}$ \\
\hline Tabat & Compact & $7.3 \mathrm{~cd}$ & (1.2) $1.3 \mathrm{c}$ & $(0.50) 1.00 \mathrm{abc}$ \\
\hline Boutana & Loose & 7.1 & (3.1) $1.7 \mathrm{abc}$ & (0.32) 0.91 bcde \\
\hline Bashair & Loose & 6.4 & (1.3) $1.3 \mathrm{c}$ & $(0.17) 0.82 \mathrm{cde}$ \\
\hline Arfa Gadamak & Compact & $12.3 \mathrm{ab}$ & (2.8) $1.7 \quad a b c$ & $(0.29) 0.89$ bcde \\
\hline Um Benain & Compact & $12.3 \mathrm{ab}$ & (2.0) $1.6 \mathrm{bc}$ & (0.13) $0.81 \mathrm{de}$ \\
\hline Meheariba & Loose & $5.6 \mathrm{~d}$ & (1.6) $1.4 \mathrm{bc}$ & (0.21) 0.84 bcde \\
\hline Karamaka & Loose & $10.1 \mathrm{bc}$ & (2.1) $1.5 \mathrm{bc}$ & $(0.20) \quad 0.84$ bcde \\
\hline Mogod & Compact & $11.5 \mathrm{ab}$ & $(6.8) 2.5 \mathrm{a}$ & (0.26) 0.87 bcde \\
\hline Wad Akar & Compact & $14.3 \mathrm{a}$ & (2.4) $1.6 \mathrm{bc}$ & $(0.50) \quad 0.99$ abc \\
\hline ICSV 93075 & Semi-compact & $10.4 \mathrm{bc}$ & (2.7) $1.8 \mathrm{abc}$ & $\begin{array}{lll}(0.50) & 1.00 & \mathrm{ab}\end{array}$ \\
\hline Bs. D.6 & Semi-compact & $5.5 \mathrm{~d}$ & (1.7) $1.4 \mathrm{bc}$ & $(0.39) \quad 0.94$ bcde \\
\hline
\end{tabular}


Evaluation of Some Sorghum Genotypes for the Susceptibility to Sorghum Head Bug Eurystylus Sp (Hemiptera; Miridae) in the Blue Nile State, Sudan

\begin{tabular}{|l|c|c|c|cc|}
\hline Edo. 16 dw & Semi-compact & $4.4 \mathrm{~d}$ & $(1.1) 1.2 \mathrm{c}$ & $(0.08)$ & $0.76 \mathrm{e}$ \\
\hline Kolum & Compact & $11.0 \mathrm{ab}$ & $(2.7) 1.8 \mathrm{abc}$ & $(0.42)$ & 0.96 bcd \\
\hline Torkash & Compact & $12.0 \mathrm{ab}$ & $(4.4) 2.2 \mathrm{ab}$ & $(0.38)$ & $0.93 \mathrm{bcde}$ \\
\hline Wad Yapis & Compact & $13.5 \mathrm{ab}$ & $(2.5) 1.7 \mathrm{abc}$ & $(0.89) 1.14 \mathrm{a}$ \\
\hline SE & & 1.2 & 0.29 & & 0.06 \\
\hline C.V\% & & 21.4 & 29.8 & & \multicolumn{2}{c|}{11.2} \\
\hline
\end{tabular}

Means followed by the same letter $(s)$ are not significantly different

Some data transformed to $\sqrt{ } x+0.5$

Means in parenthesis are actual data

\section{Season 2015/2016}

From the results obtained there was a significant difference between the genotypes in number of head bugs/head in the first and second counts. Significant differences were found between genotypes in number of bugs/panicle and the results are shown in (Table 3). In the first count the highest number of bugs/panicle was recorded on Wad Ahmed followed by Mogod, Torkash and Wad Yapis, and the lowest bugs/panicle was recorded on Karamaka followed by Basheir, BS. D6 and Edo $16 \mathrm{dw}$. In the second count, the highest number of head bugs was recorded on Um Benain followed by Mogod, Kolum and Wad Ahmed and the lowest was recorded on Karamaka followed by Boutana and Meheariba (Table 3).

Wad Acar significantly gave the highest yield followed by KCSV93075, BS.D6 and Wad Ahmed (Table 3)

Table3. Mean number of sorghum head bugs / panicle and yield for different sorghum genotypes, season $2015 / 2016$

\begin{tabular}{|l|c|c|c|c|}
\hline \multirow{2}{*}{ genotype } & \multirow{2}{*}{ Compactness } & \multicolumn{2}{|c|}{ No. of bug/panicle } & \multirow{2}{*}{ Yield ton/fed } \\
\cline { 3 - 4 } & & $\mathbf{1}^{\text {st }}$ count & $14.1 \mathrm{bc}$ & $1.5 \mathrm{abc}$ \\
\hline Wad Ahmed & Compact & $12.3 \mathrm{a}$ & $8.4 \mathrm{fgh}$ & $1.4 \mathrm{abc}$ \\
\hline Tabat & Compact & $7.2 \mathrm{bc}$ & $6.8 \mathrm{gh}$ & $1.5 \mathrm{abc}$ \\
\hline Boutana & Loose & $6.1 \mathrm{c}$ & $9.6 \mathrm{efg}$ & $1.0 \mathrm{de}$ \\
\hline Basaheir & Loose & $4.3 \mathrm{c}$ & $10.3 \mathrm{def}$ & $1.1 \mathrm{de}$ \\
\hline Arfa Gadamak & Compact & $6.7 \mathrm{bc}$ & $17.7 \mathrm{a}$ & $1.1 \mathrm{de}$ \\
\hline Um Benain & Compact & $9.3 \mathrm{ab}$ & $6.9 \mathrm{gh}$ & $1.2 \mathrm{~cd}$ \\
\hline Meheariba & Loose & $4.9 \mathrm{c}$ & $6.4 \mathrm{~h}$ & $0.9 \mathrm{~cd}$ \\
\hline Karamaka & Loose & $4.2 \mathrm{c}$ & $16.1 \mathrm{ab}$ & $1.1 \mathrm{de}$ \\
\hline Mogod & Compact & $11.6 \mathrm{a}$ & $10.7 \mathrm{def}$ & $1.7 \mathrm{a}$ \\
\hline Wad Akar & Compact & $9.5 \mathrm{ab}$ & $9.5 \mathrm{efg}$ & $1.6 \mathrm{abc}$ \\
\hline KCSV93075 & Semi-compact & $5.9 \mathrm{c}$ & $9.9 \mathrm{efg}$ & $1.6 \mathrm{abc}$ \\
\hline BS.D6 & Semi-compact & $4.9 \mathrm{c}$ & $7.4 \mathrm{fgh}$ & $0.6 \mathrm{f}$ \\
\hline Edo 16 dw & Semi-compact & $4.9 \mathrm{c}$ & $14.2 \mathrm{bc}$ & $1.2 \mathrm{~cd}$ \\
\hline Kolum & Compact & $9.7 \mathrm{ab}$ & $12.2 \mathrm{cde}$ & $1.1 \mathrm{de}$ \\
\hline Torkash & Compact & $10.9 \mathrm{a}$ & $13.4 \mathrm{bcd}$ & $1.3 \mathrm{bcd}$ \\
\hline Wad Yapis & Compact & $10.7 \mathrm{a}$ & 3.3 & 0.31 \\
\hline LSD & & 2.9 & 17.9 & 14.6 \\
\hline C.V\% & & 23.4 & & \\
\hline
\end{tabular}

Means followed by the same letter ( $s$ ) are not significantly different

\section{DiscUSSION}

Generally the developed compact-panicle, shortduration cultivars evaluated had a higher population of head bugs, however, the variety Kramaka which is loose panicle type had a high number of head bugs This is in agreement with Leuschner (1995) who reported that outbreaks of head bugs in southern and eastern Africa are mainly associated with newly developed compact-panicle, short-duration cultivars (120130 days).
From the results obtained there were significant difference between the genotypes in number of head bugs/head in the first and second counts, the highest number was recorded on improved compact and semi-compact heads (Mogod, ICSV93075, Wad Ahmed, Um Benain, Arfa Gadamak, Wad Akar,...). This results is in agreement with Ajayi, et. al., (2001) who reported that head bug incidence was generally higher on improved compact sorghum cultivars.

The lowest head bugs/panicle were recorded on the semi-compact and loose panicle genotypes, 
e.g., (Meheariba, Basheir and Botana)in the two counts. Tadesse (1986) reported that loose heads of traditional cultivars had a fewer head bugs, aphids and bollworm. Sharma and lopez(1992) reported, resistant genotypes have long glumes and cover the grain over a period of 20 days after flowering, compared with 6-8 days in the susceptible controls CSH I, CSH 5, and CSH 9.

Traditional landrace sorghums in eastern and southern Africa flower in 150 days or more. Anthesis occurs after the peak of the rains, and since the grain matures under declining rainfall and humidity, these conditions do not favor head bugs development. Lower head bug populations are, also, associated with loose-panicle types (traditional landrace sorghums) Nwanze (1985).

\section{Summary AND CONCLUSION}

- Generally the compact headed genotypes, (Wad Ahmed, Um Benain), showed the highest number of bugs. However, the variety Kramaka which is loose panicle type had a high number of head bugs.

- The lowest number of head bugs was recorded on loose and semi-compact head, (Meheariba, Basheir and Botana)

\section{REFERENCES}

[1] Ajayi, O. and Tabo, R. (1995). Effect of crop management practices on Eurystylus immaculatus on Sorghum. Panicle Insect Pests of Sorghum and Pearl Millet, Proceedings of an International Consultative Workshop 4-7 Oct 1993 ICRISAT Sahelian Center . International Crop Research Institute for The Semi-Arid Tropic, Patancheru, 502 324, India, P. $233-$ 236

[2] Ajayi, O., Sharma H. C., Tabo R., Ratnadass A. and Doumbia Y. O.(2001). Incidence and distribution of the sorghum head bug, Eurystylus oldi Poppius (Heteroptera: Miridae) and other panicle pests of sorghum in West and Central Africa. Insect Sci. Applic. Vol. 21, No. 2, 2001, pp. 103-111
[3] Leuschner, K. (1995). Insects pests of sorghum in Eastern and Southern Africa.. In: Panicle insects of sorghum and pearl millet: Proceedings of an International Consultative Workshop, 4-7 October 1993, ICRISAT Sahelian Centre, Niamey, Niger (Nwanze, K.F., \& Youm, O., Eds.). Patancheru 502 324, Andhra Pradesh, India: International Crop Research Institute for the Semi-Arid Tropics. Pages 49-56.

[4] Nwanze, K.F. (1985). Sorghum insect pests in West Africa. Proceeding of International Sorghum Entomology Workshop, 15-21 July 1984. Texas A \& M. University, U.S.A. pp: 3743

[5] Ratnadass, A. and Ajayi, O. (1995). Panicle insect pests of sorghum in West Africa. Pages 29-38. In: Panicle insects of sorghum and pearl millet: Proceedings of an International Consultative Workshop, 4-7 October 1993, ICRISAT Sahelian Centre, Niamey, Niger International Crop Research Institute for the Semi-Arid Tropics. Pages 29-38.

[6] Sharma, H.C., and Lopez, V.F. (1992). Screening for plant resistance to sorghum head bug, Calocoris angustatus Leth. Insect Science and its Application 13:315-325.

[7] Sharma, H.C., Doumbia, Y.O. and Diorisso, N.Y. (1992). A head cage technique to screen sorghum for resistance to Mirid head bug, Eurystylus immaculatus Ohd. in West Africa. Insect Science and its Application 13: 417-427

[8] Showemimo, F. A. (2005). Genetic expression of Eurystylus oldi (Poppius) resistance in two Sorghum crosses, Department of Plant Science Institute for Agricultural Research. P.M.B. 1044. Ahmadu Bello University. Samaru, Zaria, Tropical and Subtropical Agro-ecosystems, 5 (2005): $75-78$.

[9] Tadesse A. (1986). Major insect problem on sorghum in Ethiopia and strategies for their control. Pages $216-238$ in proceeding of fourth regional workshop on sorghum and millet improvement in Eastern Africa 5 - 12 Jul. 1986

[10] Thabit A. H.(2015). Economics of Sorghum Production under Traditional Farming Systemin Nyala Governate of South Darfur State, Sudan. ARPN Journal of Science and Technology. P 74.

Citation: Y. A., Eisa, Ali E. A., et al. "Evaluation of Some Sorghum Genotypes For The Susceptibility To Sorghum Head Bug Eurystylus Sp (Hemiptera; Miridae) In The Blue Nile State, Sudan". International Journal of Research in Agriculture and Forestry 4.4 (2017): 1-4.

Copyright: (C) 2017 Y. A., Eisa, et al. This is an open-access article distributed under the terms of the Creative Commons Attribution License, which permits unrestricted use, distribution, and reproduction in any medium, provided the original author and source are credited. 